\title{
CORRECTION
}

\section{Effect of aerobic exercise on cognition in younger adults}

A randomized clinical trial

Neurology ${ }^{\circledR}$ 2019;93:185. doi:10.1212/WNL.0000000000007292

In the article "Effect of aerobic exercise on cognition in younger adults: A randomized clinical trial" by Stern et al., ${ }^{1}$ published ahead of print on January 30, 2019, the keys for figures 2 and 3 should appear as in the accompanying corrected figures. The editorial office regrets the errors.

\section{Reference}

1. Stern Y, MacKay-Brandt A, Lee S, et al. Effect of aerobic exercise on cognition in younger adults: a randomized clinical trial. Neurology 2019;92:e905-e916.

Figure 2 Change in aerobic capacity

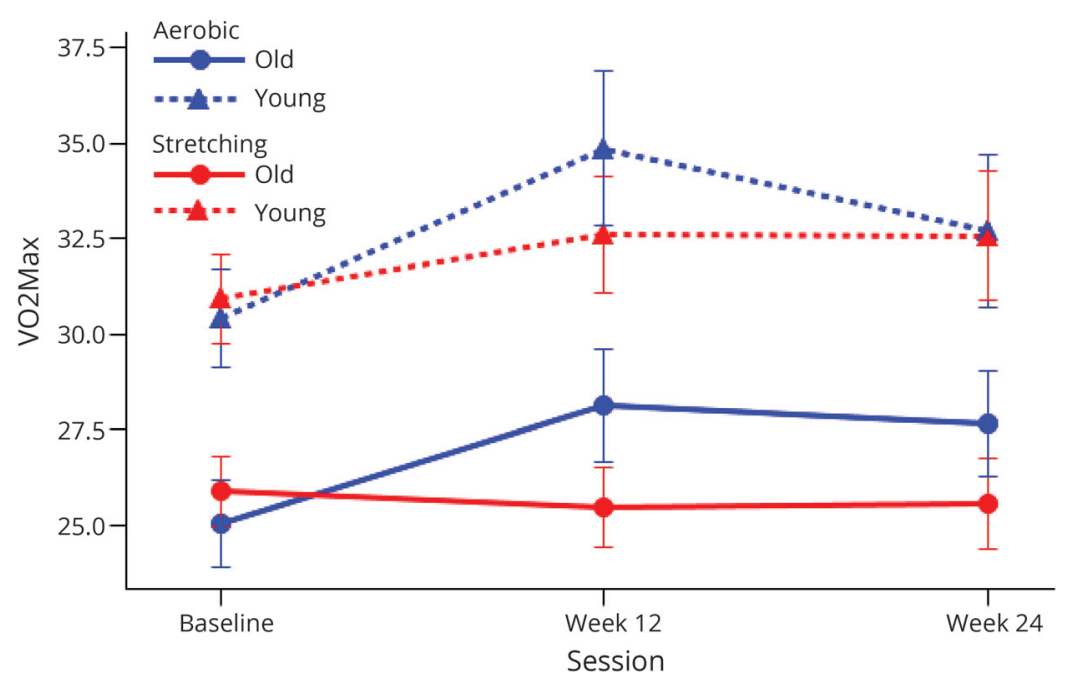

Aerobic capacity $\left(\mathrm{VO}_{2}\right.$ max) at each study visit. Data are shown for each study condition by age (split at median, age 38) and condition.

Figure 3 Change in executive function

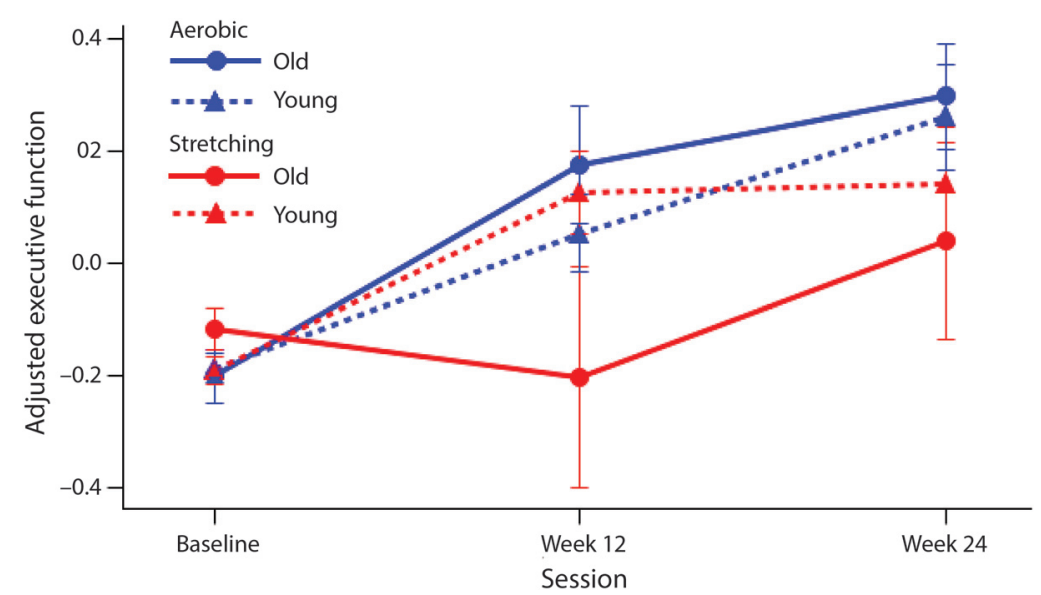

Executive function is presented at each study visit by condition in 2 age groups. Age was dichotomized using median split (38 years old). Executive function scores, measure by a summary Z score, are adjusted for age as a continuous variable, IQ, education and baseline executive function. 


\section{Neurology}

Effect of aerobic exercise on cognition in younger adults: A randomized clinical trial Neurology 2019;93;185

DOI 10.1212/WNL.0000000000007292

This information is current as of July 22, 2019

Updated Information \& Services

References

Permissions \& Licensing

Reprints including high resolution figures, can be found at: http://n.neurology.org/content/93/4/185.full

This article cites 1 articles, 1 of which you can access for free at: http://n.neurology.org/content/93/4/185.full\#ref-list-1

Information about reproducing this article in parts (figures,tables) or in its entirety can be found online at:

http://www.neurology.org/about/about_the_journal\#permissions

Information about ordering reprints can be found online:

http://n.neurology.org/subscribers/advertise

Neurology ${ }^{\circledR}$ is the official journal of the American Academy of Neurology. Published continuously since 1951, it is now a weekly with 48 issues per year. Copyright @ 2019 American Academy of Neurology. All rights reserved. Print ISSN: 0028-3878. Online ISSN: 1526-632X.

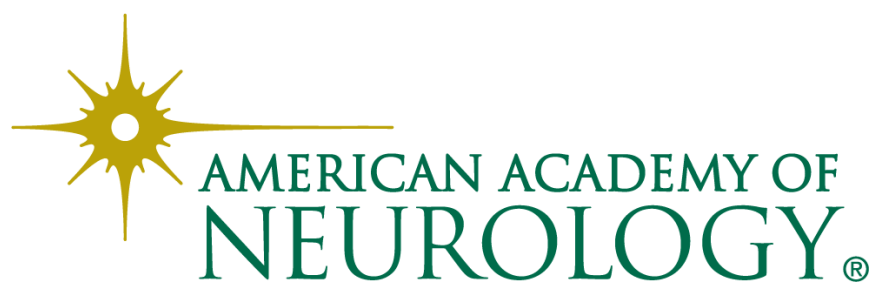

